\title{
Exploring smallholders' cultural beliefs and their implication for adaptation to climate change in North-Western Nigeria
}

Article

Accepted Version

Jellason, N. P. ORCID: https://orcid.org/0000-0002-5583354X, Conway, J. S. and Baines, R. N. (2020) Exploring smallholders' cultural beliefs and their implication for adaptation to climate change in North-Western Nigeria. The Social Science Journal. ISSN 1873-5355 doi:

https://doi.org/10.1080/03623319.2020.1774720 Available at https://centaur.reading.ac.uk/91858/

It is advisable to refer to the publisher's version if you intend to cite from the work. See Guidance on citing.

Published version at: https://www.tandfonline.com/doi/abs/10.1080/03623319.2020.1774720?journalCode=ussj20 To link to this article DOI: http://dx.doi.org/10.1080/03623319.2020.1774720

Publisher: Taylor \& Francis

All outputs in CentAUR are protected by Intellectual Property Rights law, including copyright law. Copyright and IPR is retained by the creators or other copyright holders. Terms and conditions for use of this material are defined in the End User Agreement. 


\section{CentAUR}

Central Archive at the University of Reading

Reading's research outputs online 


\section{Introduction}

Feeding the increasing world population amidst different challenges such as change in consumption habits, water shortages, energy crises, and poverty has been the concern of policy makers since about a decade ago (Godfray et al., 2010; Hanjra \& Qureshi, 2010; Royal Society, 2009). More recently, climate change and impacts have exacerbated these challenges (Abiodun, Salami, \& Tadross, 2011; World Bank, 2019). Impacts from climate change vary geographically with more extreme and longer drought experienced in sub-Saharan Africa compared to other regions of the world (IPCC, 2012). Various reports and research (Boko et al., 2007; IPCC, 2012) suggest that sub-Saharan Africa will be more exposed due to poor adaptive capacity, endemic poverty, poor institutional capacity and dependence on rain-fed agriculture leading to heightened food insecurity and malnutrition.

Adaptation to extreme climatic conditions is a time tested approach (Dixon, Stringer, \& Challinor, 2014) and it is advocated by researchers and scientists to enable already vulnerable farmers to adjust to the impacts of global climate change (W. N. Adger, Barnett, Brown, Marshall, \& O'Brien, 2012; Jones \& Boyd, 2011; Kurukulasuriya et al., 2006; Murphy, Tembo, Phiri, Yerokun, \& Grummell, 2016). Adaptation refers to the change in socioecological systems in response to perceived or real climatic stimuli or impacts, to lessen the effect of climate change (IPCC, 2001). Many factors determine adaptation actions. For example, culture and belief systems play a significant role in influencing adaptation behaviours of susceptible populations (W. N. Adger et al., 2012; Artur \& Hilhorst, 2012; Jones \& Boyd, 2011; Salite \& Poskitt, 2019). Cultural beliefs promoted by religion could result in maladaptation (W. N. Adger et al., 2009; Murphy et al., 2016) where farmers believe climate change is caused by God and when prayers are offered, their problems will be solved (Salite, 2019). According to Kirkpatrick (2005), prayer only serves to offer psychological relief in times of crises and may constrain practical adaptation. Although smallholder farmers possess vast experiential 
knowledge and rely on their time-tested approaches to solve farming and weather related problems (Dei, 1994), the constraints of relying majorly on prayer could be overcome at a smaller-scale through educating farmers about the scientific basis of climate change and the need to take action, at a larger scale (Jellason, Baines, Conway, \& Ogbaga, 2019). Overcoming the notion of reliance on prayer could entail disruptive changes that will encompass altering deeply held value systems and structures thereby distorting existing ethnic, historical and cultural identities (W. N. Adger et al., 2009). However, cultural beliefs have also received recognition as key determinants of adaptation to disaster and risks, based on their influence on the attitude towards such hazards (Salite, 2019).

In this paper, we explore cultural beliefs such as prayers and sacrifices as climate change adaptation strategies of smallholder farmers in Zango and Kofa communities to understand whether currently utilised practices ensure adaptation or result in maladaptation and consequently leading to vulnerability (Antwi-Agyei, Dougill, Stringer, \& Codjoe, 2018). Under a high vulnerability and low adaptive capacity scenario, climate change effects may limit the potential to sustainably adapt (IPCC, 2012). Moreover, a body of knowledge exists on the role of socio-cultural beliefs in promoting adaptation (W. N. Adger et al., 2009; Artur \& Hilhorst, 2012; Cutter, 2006; Schuman, Dokken, van Niekerk, \& Loubser, 2018). However, not much research has been done on the consequences of these socio-cultural beliefs in adaptation outcomes. Beliefs are dynamic as opposed to being static and what is today considered culturally significant, changes with time (McNeeley \& Lazrus, 2014). This presents an important research gap since not all intended responses by farmers in Zango and Kofa communities in North-Western Nigeria lead to adaptation. This paper is organised as follows: First, we explore the role of cultural beliefs in climate change adaptation. Cultural beliefs in this instance refer to religious beliefs and is used interchangeably with religion. Secondly, the paper describes the local experiences and regional awareness of climate change and the 
responses. Lastly, we reflect on the implication of religious beliefs, prayers and sacrifices as climate change adaptation responses. We consider the role of religious beliefs in promoting maladaptation or vulnerability as the predominant religion in the study areas was Islam. In addition, the relationship between religious beliefs and climate change adaptation are discussed in the context of different religions including Christianity and African traditional religion. 


\section{Exploring cultural (religious) beliefs, adaptation, and vulnerability}

This study is informed by the society-nature discourse on the interaction of humans and their natural environment (McNeeley \& Lazrus, 2014). This is underpinned by the religious belief-climate change adaptation theory that socio-cultural beliefs about society and nature influences climate change adaptation (W. N. Adger et al., 2009; McNeeley \& Lazrus, 2014; Murphy et al., 2016; Schuman et al., 2018). Religion and spirituality play a central part in the life of Africans (Dei, 1994) where it is viewed as a source of hope (Pew Forum, 2010) and it is essential in understanding human knowledge of ecology, views about nature and the role played by religious beliefs on adaptation to climate change (Schuman et al., 2018).

Religion broadly refers to the practices and beliefs promoted by groups and individuals in line with mysticism, spirituality and trust in divinity, as represented by formal institutions that act as custodians of organised religion and also reflected in informal belief systems through folktales and mythology (Murphy et al., 2016; Schipper, 2010). For example, it is believed that the Egyptians attached supernatural significance to every aspect of their lives and attribute same to a specific god (Banham, no date). Mbiti (2015) argues that for Africans, religion can be likened to 'an ontological phenomenon' that relates to the notion of existence and being. Traditional African religions do not view nature as a separate entity but rather as being filled with a religious connotation (Mbiti, 2015). Most African rites, ancestral beliefs and rituals directly link to nature (Olupona, 2006), hence it is reasonable for these beliefs to influence the attitude of African farmers to climate change adaptation (Schuman et al., 2018).

Hulme (2009) opines that human beliefs about the supernatural, the transcendent, the spiritual, and the role of humans as 'moral agents', determine course of action and responsibility to care for nature and fellow humans. Islam, Christianity and the African religion hold a common 
consensus that 'nature was created by God' or a supernatural being with humans interacting with nature, hence humankind may or may not be willing to adapt to climate change (Schuman et al., 2018) thereby leading to vulnerability. Vulnerability is defined by W. Adger (2006) as the condition of susceptibility to risk from exposure to pressures linked to social and climate change due to the absence of an adaptive capacity. Vulnerability is subjective and depends largely on the capability of the subject facing risk to cope with it as some systems and human populations are more vulnerable compared to others (Mehar, Mittal, \& Prasad, 2016; Reed \& Stringer, 2016).

Several factors have been identified as responsible for vulnerability experiences. For example, lack of dynamic capital such as knowledge about climate change occurrence and assets in addition to other factors (e.g. socio-cultural, financial capital, ecological factors and lack of capacity) (Bandura, 1997; Kuruppu, 2009; Salite \& Poskitt, 2019). The socio-cultural factors include religious beliefs about God or Allah (God in Islam) as the cause of climate change and prayer or sacrifice as the means of adaptation (Ashraf \& Routray, 2013; Dumenu \& Obeng, 2016; Fountain, Kindon, \& Murray, 2004; Kuruppu, 2009; Murphy et al., 2016; Orlove, Roncoli, Kabugo, \& Majugu, 2010; Salite, 2019; Schuman et al., 2018; Slegers, 2008). It is suggested that religious beliefs promote adaptation through building social capital (Schipper, 2010). Social values underpinned by spirituality and religion have been linked to adaptation decision-making in response to climate change (W. N. Adger et al., 2012; Schuman et al., 2018). Several adaptation studies in sub-Saharan Africa, report prayer as an adaptation strategy to climate change related problems (Abaje, 2014; Farauta, Egbule, Idrisa, \& Agu, 2011; Mabuku, Senzanje, Mudhara, Jewitt, \& Mulwafu, 2019).

Prayer has been used as a means of controlling disasters. For example, in a study on religion, witchcraft and HIV-AIDS in Malawi, the people argued that they had no control over disasters, 
deaths and diseases when they were ravaged by HIV-AIDS and so they resorted to prayers and leaving everything to God to determine (Forster, 1998). While prayers are integral to the life of people of faith (Chitando, 2017), this attachment to a supernatural being is argued to mostly provide a psychological satisfaction in times of crisis according to Kirkpatrick (2005). As such, no empirical evidence exist on the efficacy of prayers in changing the outcome of these disasters (Forster, 1998; Schipper, 2010). Ceremonies are mostly made by people to appreciate nature and seek protection from hazards which portrays the relevance attached to religious and traditional belief systems in community resilience promotion (Hiwasaki, Luna, Syamsidik, \& Marçal, 2015). These beliefs that promote religious attribution of the causes of life events such as climate change lead to avoidant behaviour to adapt which are often referred to as maladaptive behaviours (Chitando, 2017; Grothmann \& Patt, 2005; Jones \& Boyd, 2011).

Fatalistic attitudes and reliance on beliefs lead to household vulnerability (Yeletaysi, Ozceylan, Fiedrich, Harrald, \& Jefferson, 2009). For example, prayer as a climate response strategy is considered an absence of agency or a lack of an adaptive capacity (Nelson \& Finan, 2009). This is evident in contributing to community vulnerability as they lead to non-uptake of adaptation measures (Schipper, 2010; Schuman et al., 2018; Spear et al., 2015; Spear, Selato, Mosime, \& Nyamwanza, 2019). Similarly, it is suggested that vulnerability is mostly seen to be pronounced in places such as sub-Saharan Africa where people hold strongly to religion (Murphy et al., 2016). This has been demonstrated in recent studies in Mozambique (Artur \& Hilhorst, 2012; Salite, 2019) where certain communities believe natural disasters are caused by God or a result of the sinful behaviours of its members. Another study for Nigeria also supported this assertion arguing that disobeying God led to climate change effects (Abaje, 2014). Despite the importance attached to the supremacy of God as a protector, African farmers believe they could receive God's punishments when they do not act appropriately (Dei, 1994). 
These farmers also believe they will receive blessings from God in form of good rains, bumper harvests and good seasons when they act right (Banham, no date). Belief in God as source of rain could be traced to the account of the early days of humanity where the Christian Bible states that:

"In the past, he let all nations go their own way. Yet he has not left himself without testimony: He has shown kindness by giving you rain from heaven and crops in their seasons; he provides you with plenty of food and fills your hearts with joy." Acts of the Apostles 14:16-17 (NIV).

Such narratives give religious adherents the understanding that God is responsible for the changing climate, and rain or lack of it. Hence, smallholders are unable to adapt to manage climate impacts as they believe they cannot influence the outcome of their circumstances (Kuruppu, 2009). We present a conceptual framework in form of a causal network (Figure 1) to show the interactions of prayers, sacrifices, socio-cultural beliefs, and vulnerability. Positive signs show that as the variables from the point of origin of the arrows increase, the destination variable increases also and negative sign shows that as originating variable increases, destination variable decreases. 


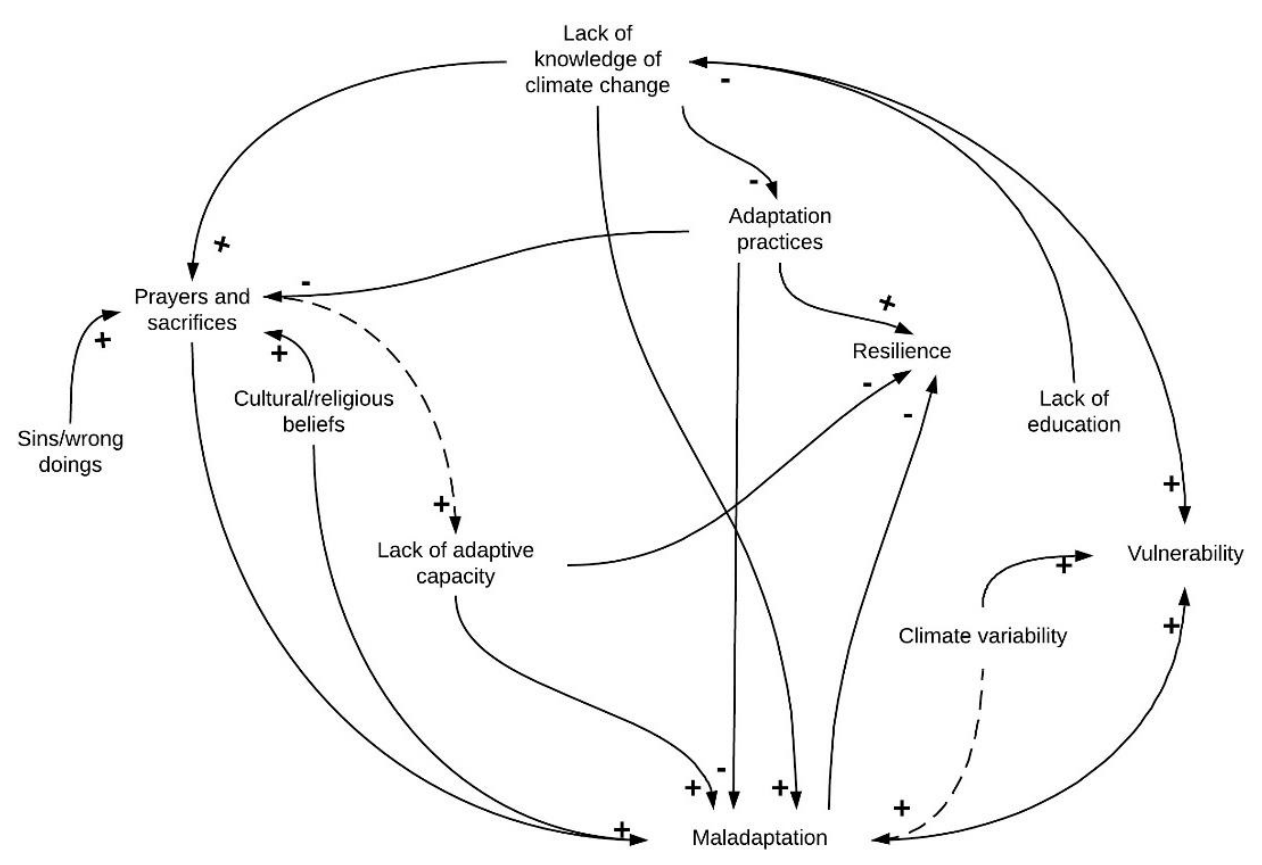

Figure 1. Causal network showing the interconnections among prayers, cultural beliefs, maladaptation, and other related variables. Full lines show evidenced causality in the literature, while dotted lines represent perceived links not yet established. 


\section{Material and methods}

3.1. The case study sites

Nigeria is contextually relevant for the study of cultural beliefs, prayer and vulnerability as it is a very religious country with about $98 \%$ of the citizens professing to either Christianity or Islam (Pew Forum, 2010). In Nigeria, agriculture is the second contributor to GDP $(22.86 \%)$ after services $(53.97 \%)$ and it is the largest single employer of labour employing about 36.5 $48.2 \%$ of the labour force (FAO, 2018; National Bureau of Statistics, 2018). Despite these contributions, agriculture is mostly practiced by smallholder farmers who constitute $88 \%$ of the farming population cultivating an average of 0.5 hectares of land, live on less than USD 1.9 a day, and are largely dependent on rain-fed agriculture thereby leading to further vulnerability (FAO, 2018). In addition, mixed crop-livestock farming systems and fishery are the predominant forms of agriculture as pastoralists' livestock management is an integral part of the livelihood in most communities. A typical Nigerian smallholder farming household has a diversified portfolio of agricultural and non-agricultural activities which serve as sources of income and a means of resilience promotion (FAO, 2018). However, due to the dependence of the Nigerian economy on land based sectors such as agriculture, and resource extraction, climate change is forecast to expose the agricultural sector to high vulnerability to extreme weather conditions that will slow the growth of the sector (UNFCCC, 2015; World Bank, 2019). Moreover, the Northern part of Nigeria which serves as the food hub of the country and where the study sites are located, is vulnerable to drought (UNFCCC, 2015).

Two communities in North-Western Nigeria (Zango and Kofa) were engaged in the study in Katsina and Kano States respectively (Figure 2). Zango is an arid farming community identified as vulnerable to climate change experiencing high temperature regimes, low rainfall amount, late onset of rain, and signs of desertification (Abiodun et al., 2011; Jellason et al., 2019). Total rainfall per annum in Zango averages $591 \mathrm{~mm}$ which supports the production of 
legumes, and cereal crops including cowpea, soybean, groundnuts, sorghum, and pearl millet. Kofa however, lies south of Zango with per annum rainfall average of $835 \mathrm{~mm}$ and legume, cereal crops, and some vegetables are grown including groundnuts, soybean, cowpea, sorghum, maize, millet, garlic, tomatoes, and onions with some irrigation practiced. Most inhabitants of Zango and Kofa which fall under the northern Nigeria, practice Islam as the predominant religion in the area and have very strong belief in God (Pew Forum, 2010). Secondary rainfall and temperature data were analysed for the period 1997 to 2017 based on the available data for the study locations from Nigerian Meteorological Agency (NiMet) and to coincide with the projections in Abiodun et al. (2011).

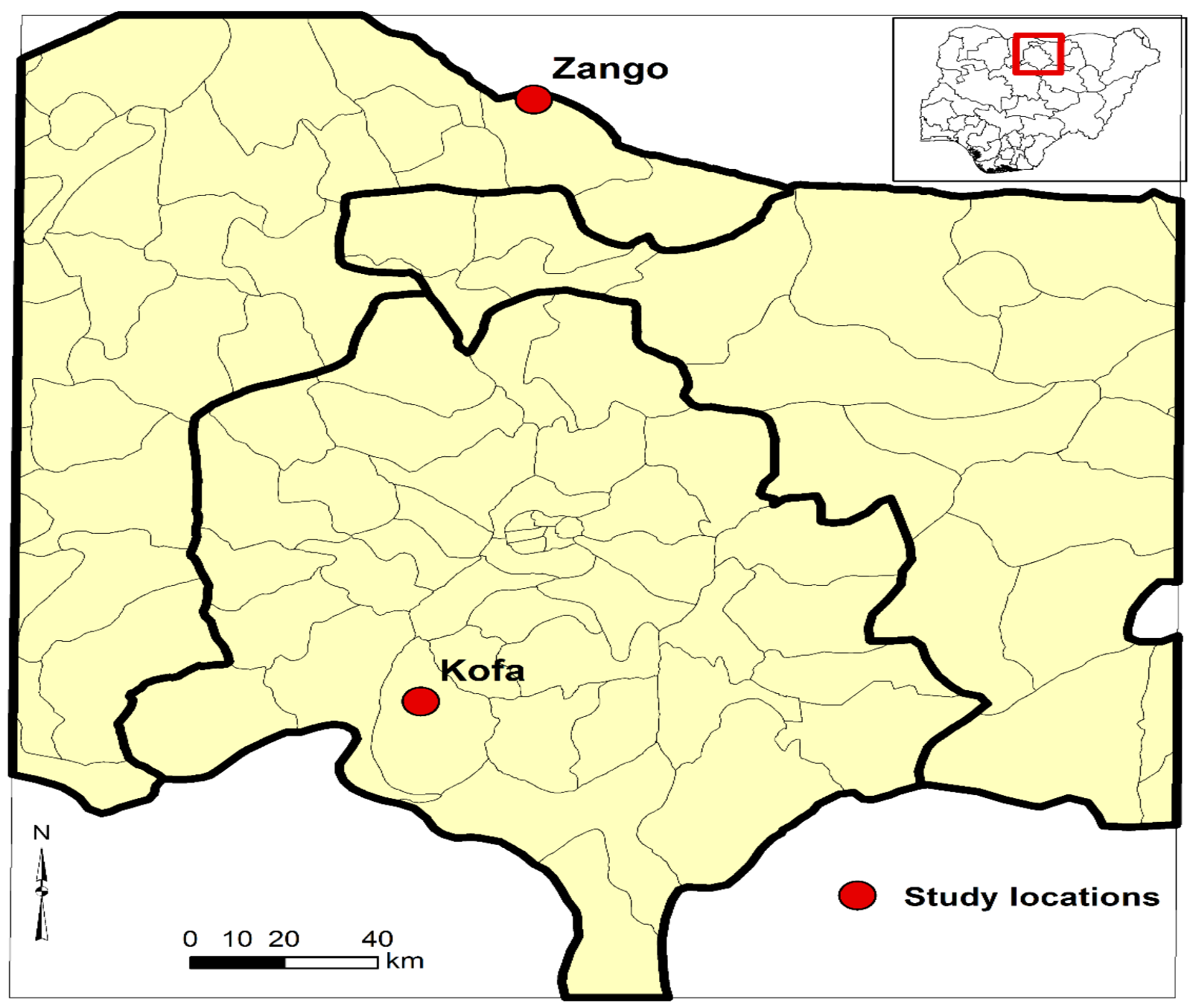

Figure 2. Map of Nigeria showing the two study communities - Zango and Kofa in Katsina and Kano States - North-Western Nigeria.Research methods 
This study was undertaken between March and May 2016 in Zango and Kofa communities. Focus group discussions (FGDs) and key informant interviews were used for data collection. A total of 6 FGDs (3 per community) comprising youth, women, and older men separately and interviews with a total of 15 people- 7 in Zango and 8 from Kofa were carried out. Interview results did not inform much of this work. Focus group discussions were held with a total of twenty-three participants in Zango (ten youth, seven women and six older male farmers) and twenty-eight in Kofa (eight youth, twelve women and eight older male farmers). Group sizes and composition for FGDs have been suggested to vary from 8-12 (Stewart \& Shamdasani, 2014), 6-10 (Morgan \& Scannell, 1998), 9-11 (Dawson, 2009), and 6-8 (Krueger, 2002). Participants were selected from the participants' list in an initial baseline study into young farmers (18-34 years), older male farmers (35 years and above) and women farmers (of all ages). The purpose of separating the groups is to reduce tensions and power imbalances between age and gender groups to ensure a wider range of opinions. The FGDs schedule were developed and implemented with participants by an experienced moderator familiar with the topic of discussion in the local language of the participants (Hausa) and lasted between 60-90 minutes. We explored the prevailing farming practices of the participants and the consequences of adaptation responses to climate change experiences. The questions were on perceptions of weather and climate variability, and the effects on household and economic activities. Questions about participant's decision-making and responses to the effects of climate change and the viability of the strategies employed were further probed. All the FGDs were audiorecorded and transcribed exactly while notes were taken in interviews. Transcribed recordings were translated from the local language to English by the corresponding author into text. From the transcribed text, data were coded into themes and sub-themes using the Nvivo qualitative data analysis software. 
We also considered historic climate data for the region to understand the trend, past experiences of weather and climate related changes (section 4.2). 


\section{Results}

The results of this study are presented in different sections to explore different themes ranging from demographic characteristics of the FGD participants and secondary climate data from the NiMet for Katsina and Kano which served as proxy for Zango and Kofa being the nearest local government areas with available climate data. Then we present results on local experiences and regional awareness of climate change, perceived effects while the last section is on existing adaptation strategies in both communities.Demographic characteristics of the FGD participants The demographic characteristics of the FGD participants showing their educational level and age range to understand the group composition are presented (Table 1). Zango community had higher percentage $(39.1 \%)$ with tertiary education while only $21.4 \%$ of participants in Kofa had tertiary level of education. Despite having the higher tertiary level of education between the two communities, Zango still had the higher percentage of participants with no education (56.5\%) compared to Kofa with $50 \%$ of participants without education. Zango had no participants with primary education.

\section{Table 1}

Characteristics of the FGD participants in Zango $(n=23)$ and Kofa $(n=28)$ communities

\begin{tabular}{lll}
\hline Community & $\begin{array}{l}\text { Highest education } \\
(\%)\end{array}$ & Age range $(\%)$ \\
\hline Zango & Tertiary (39.1) & $18-34(52.2)$ \\
& Secondary (4.3) & $35-50(30.0)$ \\
& No education (56.5) & $51 \&$ above $(17.4)$ \\
& Tertiary (21.4) & \\
Kofa & Secondary (14.3) & $18-34(54.0)$ \\
& Primary (14.3) & $35-50(35.0)$ \\
& No education (50.0) & $51 \&$ above $(11.0)$
\end{tabular}

4.2. Past Climate data for the region 
Taking the average maximum temperature for three periods $(1987-96 ; 1997-2007$ and 20082017) and based on available data, the trends in temperature for the growing season - April to October, did not show much differences between the two communities (Figures 3 and 4). The trend appears to be similar for each month over the period for both communities with very slight differences. The case is different for the rainfall data which show a wide variation (Figures 5 and 6).

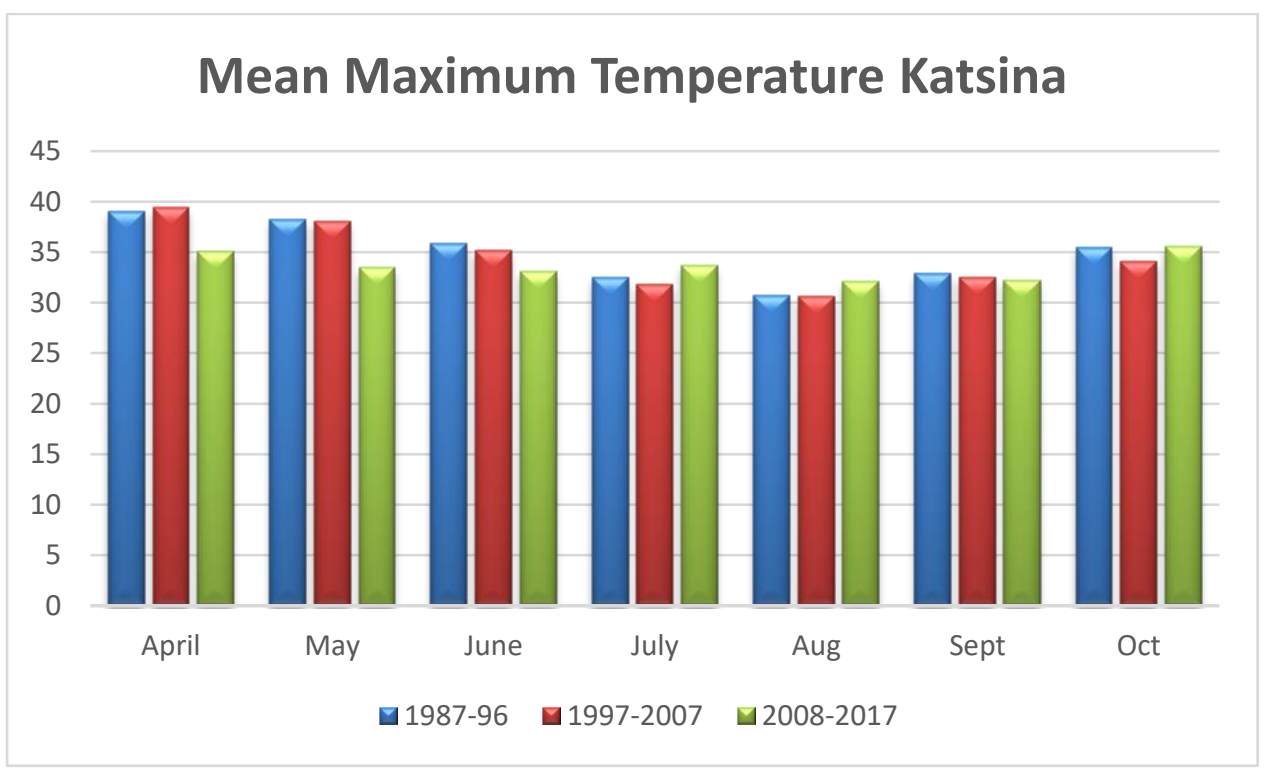

Figure 3. Mean Maximum Temperature trends for the periods 1987-96; 1997-07 and 2008-17 for the Katsina growing season being the nearest town to Zango with available temperature data.

Data source: NiMet (1987-2017). 


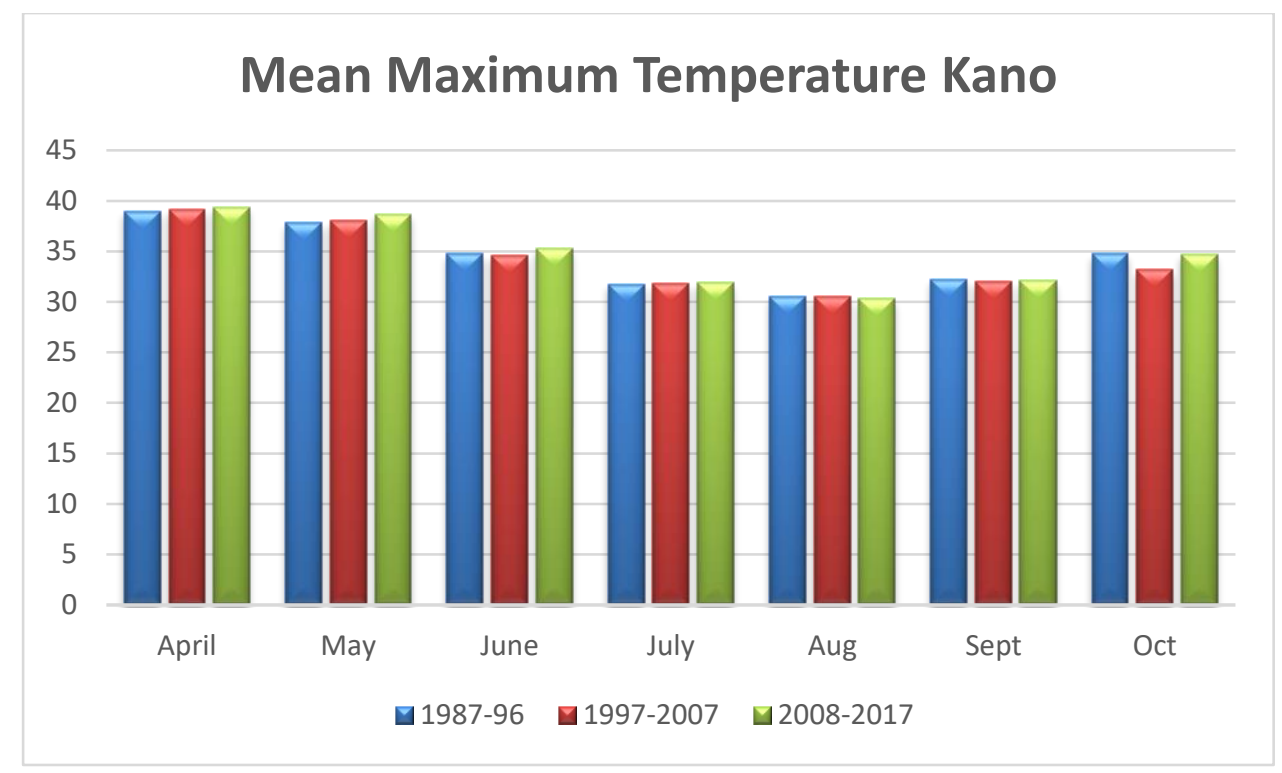

Figure 4. Mean Maximum Temperature trends for the periods 1987-96; 1997-07 and 2008-17 for the Kano growing season being the nearest town to Kofa with available temperature data. Data source: NiMet (1987-2017).

According to Abiodun et al. (2011), observed trends in past rainfall in this region for the period 1981 to 2000, suggest rainfall decreased, the time of onset prolonged and length of the raining season being shortened for Zango community while the observations for Kofa from available data are not well understood. However, the rainfall data presented here (Figures 5 and 6) show variability in the rainfall amount across months over the years without any noticeable consistency in the pattern of rainfall making it difficult for farmers to plan their cropping seasons and avoid drought at the critical stages of the crop production. Poor timing of planting could result in yield loss from poor grain formation in cereal and wilting of leaves (Blum, 2017). The average rainfall data for the growing season shows between season variability (Figure 7). 


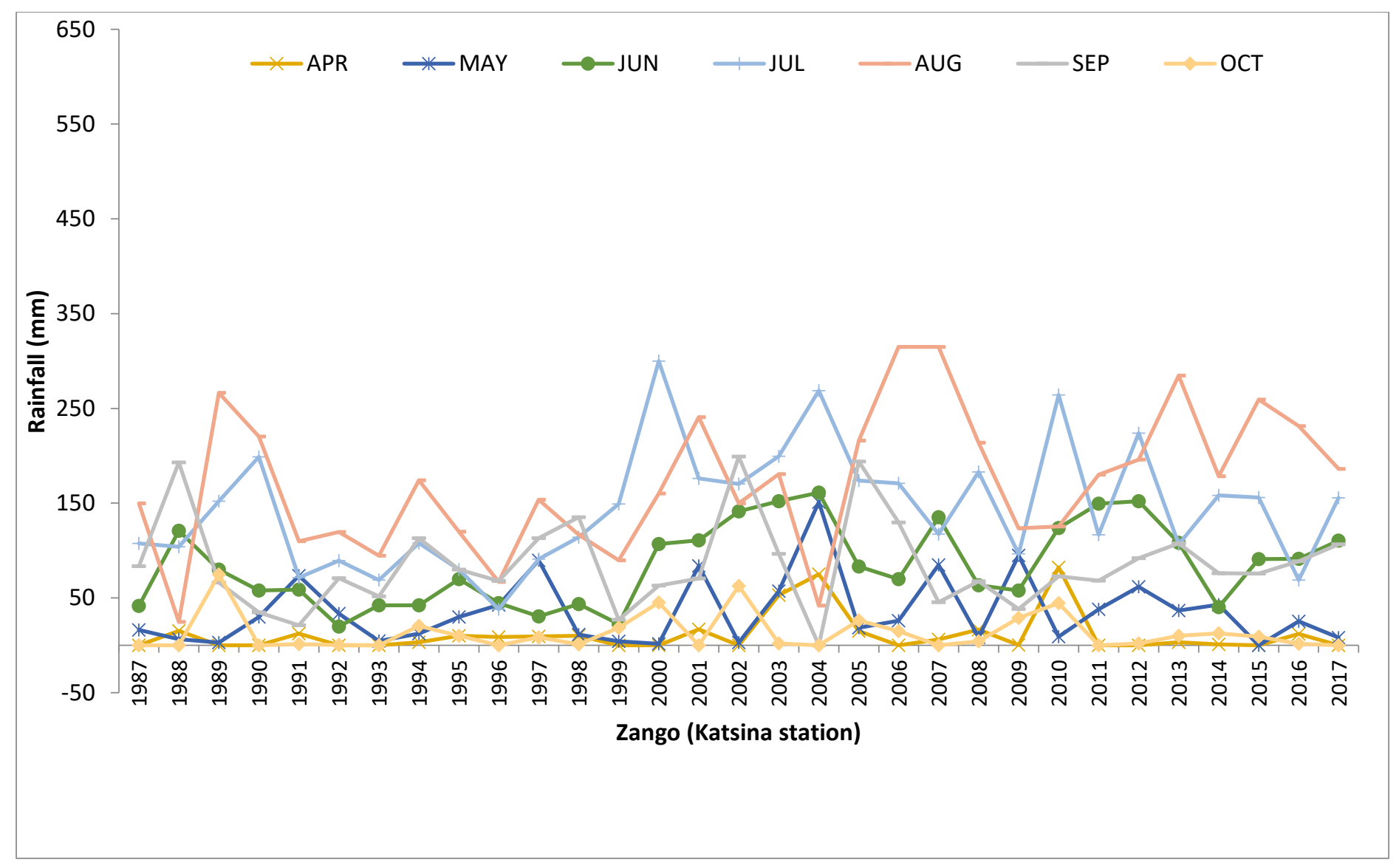

Figure 5. Average monthly rainfall amount for Katsina station (a proxy for Zango community) 1987-2017 being the nearest town to Zango with available temperature data.

Data source: NiMet (1987-2017). 


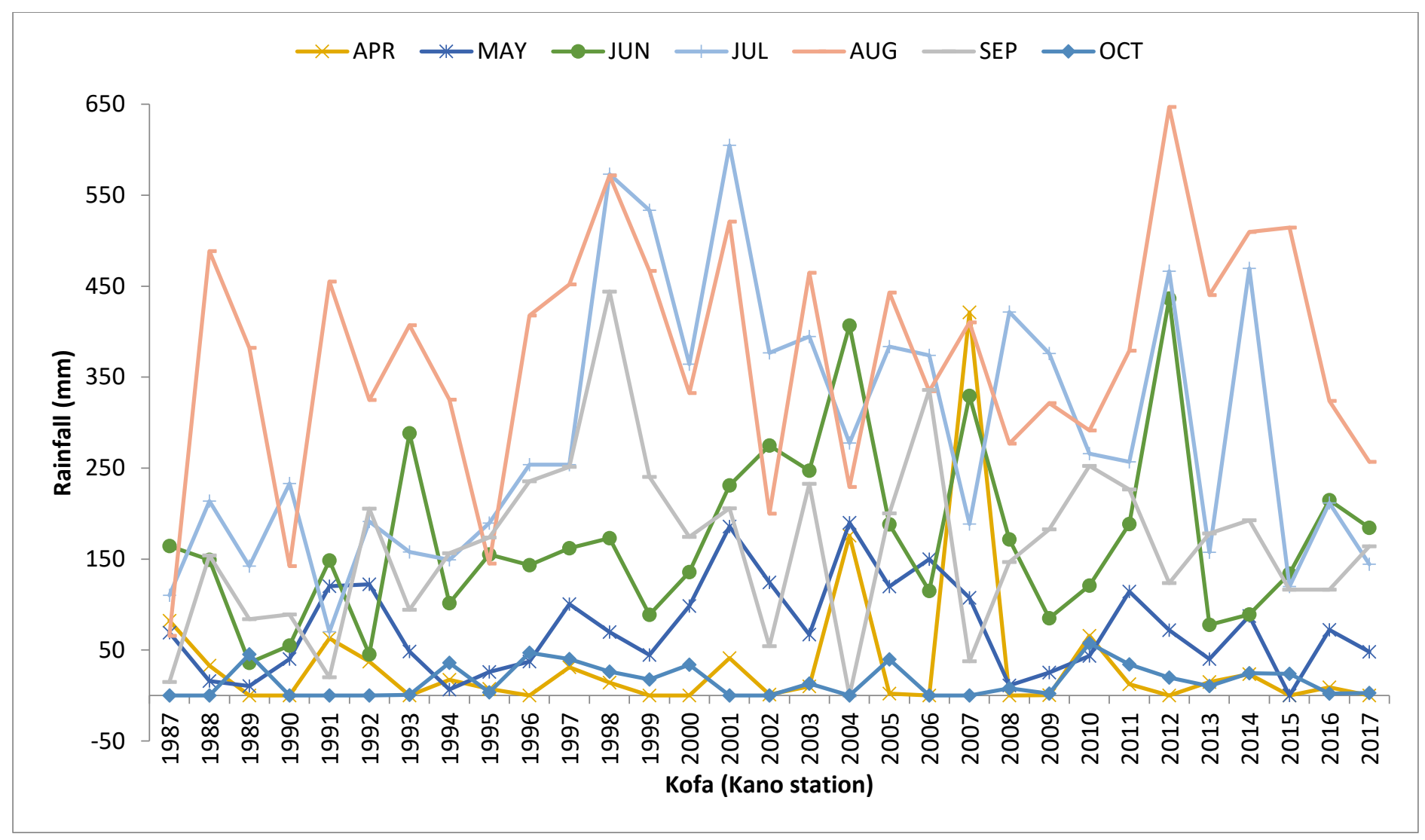

Figure 6. Average monthly rainfall amount for Kano station (a proxy for Kofa community) 1987-2017 being the nearest town to Kofa with available temperature data.

Data source: NiMet (1987-2017). 


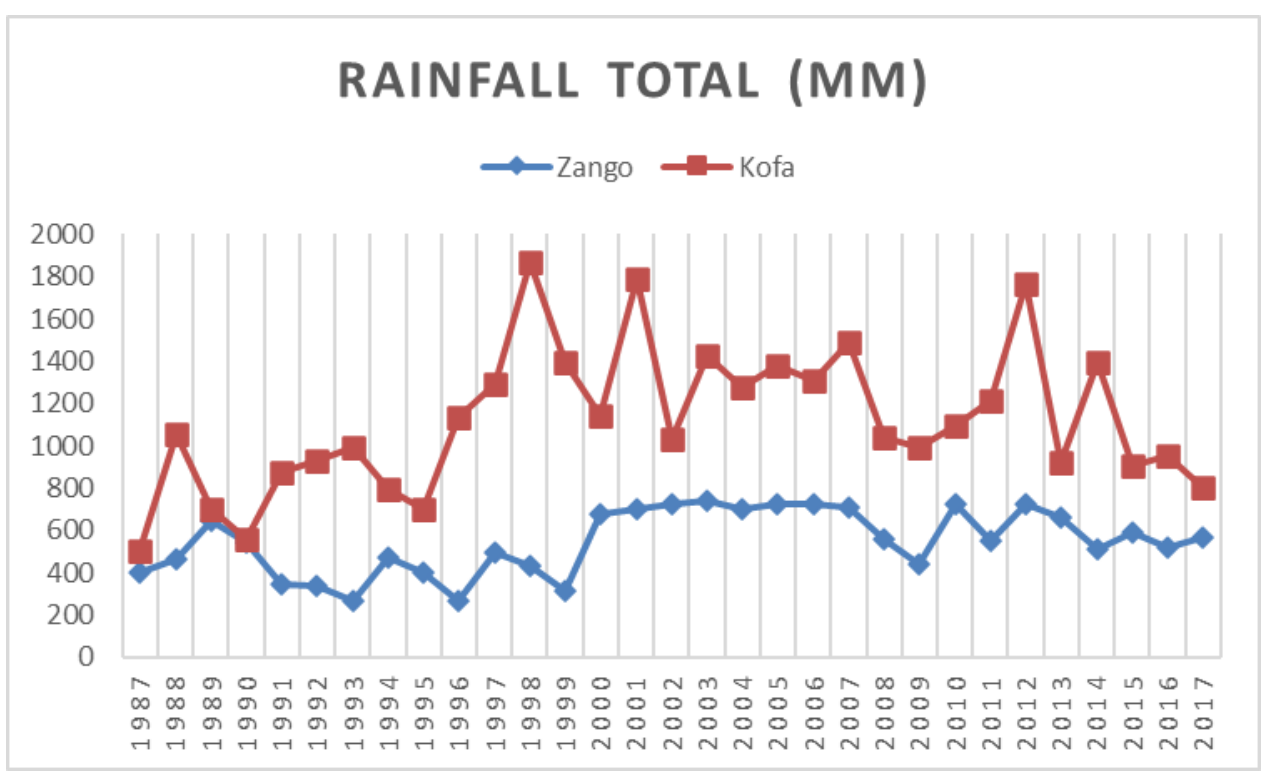

Figure 7. Average rainfall for the growing seasons for Zango and Kofa (1987-2017).

Data source: NiMet (1987-2017).

4.3. Local experiences and regional awareness of climate change and perceived effects

Participants in both Zango and Kofa communities have experienced climate change and impacts first in terms of loss of yield due to early cessation of rainfall, secondly loss of yield from temperature variability. For example, Kofa community farmers reported vegetable yield losses due to poor rainfall. As found in this study, Zango households live in a drier condition compared to their counterparts in Kofa and depend on rain-fed agriculture. Experience and awareness of the risk from climate change supports preparations towards managing the risk (Jellason et al., 2019). Available evidence portrays that both communities are knowledgeable and aware of the occurrence of climate change at local and regional scales as experienced by them or their counterparts in other locations such as the Niger Republic according to the Zango community respondents (Jellason et al., 2019). Farmers perceived rainfall variability, changes in the planting seasons, poor yields, flood, pest and diseases infestation at the local level. At 
regional scale, farmers understand drought and desertification is occurring in neighbouring Niger republic (Table 2).

\section{Table 2}

Local experience and regional awareness of climate change

\begin{tabular}{|c|c|c|}
\hline Community & Local experience & Regional awareness \\
\hline Zango & $\begin{array}{l}\text {-Rainfall fluctuation affects farmers } \\
\text { in our community. } \\
\text {-Planting seasons have changed as } \\
\text { experienced now. } \\
\text {-Rainfall shortages have affected our } \\
\text { farms. } \\
\text {-Our cowpea and groundnuts have } \\
\text { been affected by pests and diseases. } \\
\text {-Our crops have been burnt due to } \\
\text { poor rainfall. } \\
\text {-We experienced floods. }\end{array}$ & $\begin{array}{l}\text {-In the neighbouring Niger Republic, } \\
\text { we hear of how rainfall is insufficient. } \\
\text {-In the Niger Republic, people have } \\
\text { experienced loss of livestock and other } \\
\text { assets which led people to flee from } \\
\text { their communities. } \\
\text {-Desertification (Hamada*) is been } \\
\text { experienced in the Sahara (Niger). }\end{array}$ \\
\hline Kofa & $\begin{array}{l}\text {-We experience poor yields and pests' } \\
\text { infestation is higher on our farms } \\
\text { unlike in the past. } \\
\text {-We experience poor performance of } \\
\text { onions on our farms. }\end{array}$ & $\begin{array}{l}\text {-We hear of poor rainfall in } \\
\text { neighbouring states. } \\
\text {-We experience colder weather than in } \\
\text { the past. } \\
\text {-We hear on the radio that climate } \\
\text { change is happening elsewhere. }\end{array}$ \\
\hline
\end{tabular}

*Hamada is Hausa word for desert encroachment.

All the participants in the Zango-youth FGD acknowledged that climate change has effects on their livestock while all participants for the Kofa women group agreed climate change has effects on their farms leading to loss of yield thereby making food expensive. The older and youth groups in Kofa also supported this assertion, where they argued that failure of rainfall has a multiplier effect as it leads to loss of animal feed and consequently loss of manure (for soil fertility improvement). The women engage in some crop production in female headed households or in cases where the female respondent is an older woman. Younger married women were mostly not involved in farming in the communities due to cultural reasons. In terms of effects of rainfall shortages on households and farms, some groups (Kofa youth and 
women) asserted that farms and humans are affected due to drying up of wells at homes making underground water unavailable for domestic use and small-scale irrigation.

\subsection{Climate change adaptation}

A mixture of agronomic, socio-cultural and economic adaptation strategies was found in the two study communities (Table 3). While adaptation practices that are agronomic and economic in nature such as adoption of early maturing varieties, early planting and economic diversification were found in both communities, the predominant strategies were mostly sociocultural.

Table 3

Household climate change adaptation strategies used in the two communities ( $\mathrm{n}=23$-Zango; $\mathrm{n}=28$ - Kofa)

\begin{tabular}{|c|c|c|c|c|}
\hline No. & & Adaptation strategies & Zango & Kofa \\
\hline 1. & \multirow{7}{*}{ 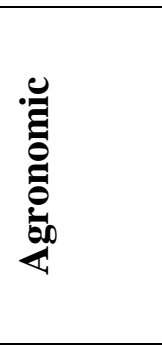 } & Early maturing crop varieties & Yes & Yes (older) \\
\hline 2. & & Dry season farming & No & Yes (women) \\
\hline 3. & & Planting trees & Yes (older) & Yes (older) \\
\hline 4. & & Early planting & Yes (older) & Yes (older, youth) \\
\hline 5. & & Tied ridges & No & Yes (older) \\
\hline 6. & & Manure application & No & Yes (older, women, youth) \\
\hline 7. & & Crop savings & No & Yes (older, youth) \\
\hline 8. & \multirow{12}{*}{ 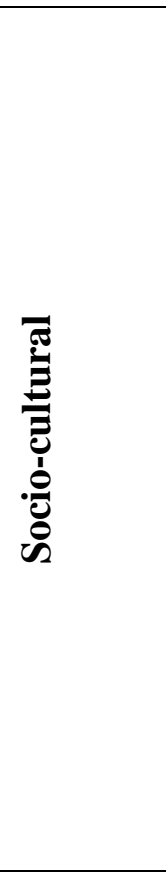 } & We only pray & $\begin{array}{l}\text { Yes (older, } \\
\text { women) }\end{array}$ & Yes (all) \\
\hline 9. & & Belief in God & No & Yes (older, women) \\
\hline 10. & & We make sacrifices & No & Yes (youth) \\
\hline 11. & & $\begin{array}{l}\text { Borrow food from neighbours } \\
\text { to repay in good season. }\end{array}$ & Yes (older) & No \\
\hline 12. & & Report to extension agents & No & Yes (women) \\
\hline 13. & & We pray & $\begin{array}{l}\text { Yes (women, } \\
\text { older) }\end{array}$ & Yes (youth) \\
\hline 14. & & God helps & Yes (women) & No \\
\hline 15. & & We make sacrifices and pray & No & I.D 8 youth \\
\hline 16. & & $\begin{array}{l}\text { We join hands with religious } \\
\text { leaders to pray }\end{array}$ & No & I.D 4 older \\
\hline 17. & & $\begin{array}{l}\text { It is God that determines what } \\
\text { happens }\end{array}$ & No & I.D 1 older \\
\hline 18. & & $\begin{array}{l}\text { We pray to ask forgiveness } \\
\text { and rain comes }\end{array}$ & - & I.D 7 youth \\
\hline 19. & & We did nothing & No & Yes (women) \\
\hline 20. & \multirow{2}{*}{$\underset{\tilde{E}}{\Theta} \cong$} & Sell livestock & No & Yes (women, older) \\
\hline 21. & & Fall back to business & No & Yes (older) \\
\hline
\end{tabular}




\begin{tabular}{llcc}
\hline 22. & Livelihood diversification & No & Yes (women) \\
23. & Sell my assets & Yes (older) & No \\
& & \\
\hline
\end{tabular}

In relation to the value of the agronomic practices employed, a participant in the Youth group in Zango (I.D 6) reported that:

“...if we don't have improved seeds, and fertilizer is not applied on our farms, it will lead to losses".

Despite the benefit of employing agronomic practices for adaptation, the socio-cultural measures were very pronounced and had more mentions across all the FGDs (Figure 8).

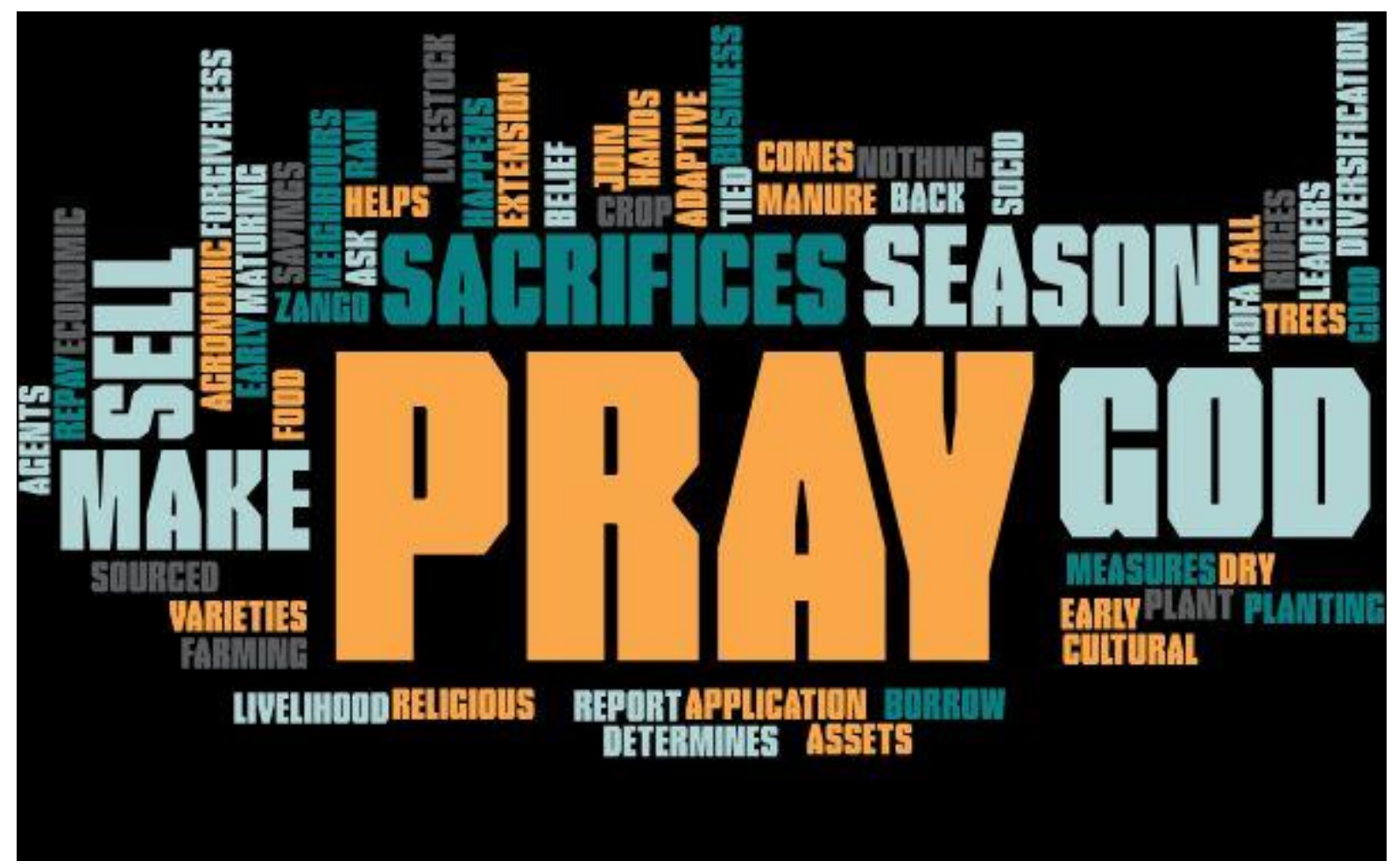

Figure 8. Word cloud produced from adaptive measures from Zango and Kofa FGDs in Table 3 without the 2 community columns.

The youth group (FGD) in Kofa asserted that climate change is caused by God therefore they make sacrifices to appease the gods because of their sins and after such sacrifices, they believe 
the rains will fall. This belief in God is further buttressed by the perception that poor seasons are signs of punishment by God as aptly captured by one participant:

"When we face rainfall shortages, we feel we have sinned, so we go and pray to ask forgiveness and our problem of rainfall scarcity gets solved (I.D 7-Kofa youth FGD)".

Despite the existence of some adaptation strategies, Kofa participants argued that they require additional support in the areas of business and farming support, dams, livestock management, early maturing and high-yielding varieties of crops, fertilizers and herbicides. Zango participants on the other hand requested support with fertilisers, support with early maturing seeds, herbicides, subsidies and loans from government or private organisations. 


\section{Discussion and conclusion}

This study explored smallholder farmers' experiences of climate change and their existing adaptation practices in Zango and Kofa communities to understand whether cultural (religious) beliefs and currently held practices enhance adaptation or result in maladaptation thereby promoting vulnerability (Antwi-Agyei et al., 2018). The results show that some adaptation practices exist in the communities such as use of early maturing varieties of crops, tied ridging, tree planting on farm, livelihood diversification, sale of assets and livestock, prayers, and sacrifices. Adapting agronomic practices such as early maturing varieties of crops aligns with N. W. Adger, Arnell, and Tompkins (2005) who suggests "planting hardier crops" such as drought tolerant crops that can tolerate climate variability. Livelihood diversification supports resilience in the short term through risk spreading. This agrees with Batterbury and Mortimore (2013) who suggest that households depend on remittances from their sons working away from home. However, this may not always be the case in the long term as strategies such as diversification were found in another study (Osbahr, Twyman, Neil Adger, \& Thomas, 2008) to be less effective for climate change adaptation in the long-term.

Practices such as selling of assets and livestock may be adaptive in the short-term, in the long term however, it may expose households to more risks when these assets get exhausted. In addition, farmers rely more on prayers and making sacrifices in some instances as a means of climate change adaptation as they believe that climate change is caused by God. Since about $50 \%$ of the participants in both communities (Table 1) reported to have no access to any form of education, this could be linked to some farmers' limited understanding of the scientific basis of climate change (Jellason et al., 2019). Belief in God as the cause of climate change was previously reported in a climate change perception study for Nigeria (Tambo \& Abdoulaye, 2013) which aligns with the findings in this study. 
Assets for adaptation were lacking for the Zango FGDs while some participants in Kofa relied on crop savings from previous seasons in case of crop failure in the current season due to uncertainties in climate variables (Table 3). Some also relied on the more traditional tactic of using livestock as an adaptation strategy. However, assets are not the only requirement for building adaptive capacity to manage vulnerability as some social skills that enhance adaptability are also very central in Zango such as borrowing food from neighbours to repay during good years. This is in line with a study of farmers' adaptation strategies in Mozambique where farmers borrowed from neighbours to repay in good seasons (Osbahr et al., 2008). These social skills include relying on social networks in case of periods of shortages as occasioned by climate change. For example, findings showed that yield and feed losses are direct consequences of the failure in rainfall and increased temperature (Section 4.3) which reflects the exposure of the study communities to climate-related stimuli due to dependence on rainfed agriculture as corroborated by Gallopín (2006). This leads to high vulnerability occassioned by unpredictability of climatic variables (UNFCCC, 2015; World Bank, 2019).

The two communities mainly differed in terms of the amount of rainfall in the growing season with rainfall in Zango being much lower than that of Kofa (Figure 6). Although the time period covered for rainfall data (31 years) is not enough period to assess climate change, it was considered a relevant period to link to farmer experiences of rainfall variations during their farming lifetimes.

Participants also reported a need for some form of support (Section 4.4) which will suggest that the prayer mostly made is not working which agrees with the findings of (Nelson \& Finan, 2009) who suggest that prayer may not be a viable adaptation strategy when faced by disaster. Hence, the tendency will be for farmers to always request support as we found in this study. These demands for support breed a culture of dependency thereby leading to further 
vulnerabilities in the absence of the support as corroborated by Westley, Carpenter, Brock, Holling, and Gunderson (2002) and Spear et al. (2015).

Despite the presence of some adaptation strategies in both communities, the underlying assumption is the tendency for maladaptation due to high reliance on prayers as an adaptation strategy (Figure 8) thereby leading to vulnerable situations in most cases. Reed and Stringer (2016) opined that lack of adaptive capacity could result in vulnerability to climate change and land degradation. Hence, the need to identify means of reducing vulnerability of farming households and communities.

Responsibility for adaptation decision-making in Zango and Kofa communities, rests with the man in male-headed households. This is in conformity with Irohibe and Agwu (2014), where they reported that male household heads were responsible for decision-making for adaptation against climate change in Northern Nigeria. This reinforces the existing power of the male spouses in the household and farming decision-making that mostly alienate women from involvement in farming in these communities and also not seeking their opinions in making such vital decisions that affect the food security of households with the women at the receiving end. Although in a few cases, household heads confer with their spouses and elderly children before making decisions to adapt.

The educational level of the household head is also seen to be critical as it influences the quality of adaptation decisions made by them. For instance, we found that about half of the participants in both communities lacked any form of formal education which could affect the quality of their adaptation decisions. Interestingly, household heads with no or limited formal education have been found to likely make adaptation decisions based on their religious or cultural understanding of rainfall formation and climate change causes (Salite, 2019). 
Religious and traditional leaders most likely play a role in terms of community adaptation decision-making in these communities as reflected in the knowledge that climate change is “caused by God". Salite (2019) suggests that smallholder farmers in Mozambique reported that their lack of gratitude to God for the previous bountiful season, abortions by teenagers and other sins they unconsciously committed were responsible for the poor seasons recorded. Hence, farmers made sacrifices as recompense for their sins and to attract rainfall from the gods to till the ground and grow their crops (Osbahr et al., 2008; Salite, 2019). Orlove et al. (2010) also found that rainfall shortages were attributed to God's displeasure with the conduct of the people in a study on indigenous climate knowledge in southern Uganda. As similarly reported in Slegers (2008), the Zango and Kofa community members being predominantly Muslims, carryout prayers in Mosques and make sacrifices as part of a ceremony to invite rains. The belief in God is likely to lead to non-adaptive behaviours (Spear et al., 2019) as we found that despite such beliefs, farmers still request for some sort of support such as fertilisers thereby leading to the argument that prayer is not a sufficient strategy for adaptation but rather carrying out tangible practices could lead to adaptation with less emphasis on prayers.

The research participants suggested that variability of climate experienced was a consequence of their 'sins' or wrong doings. This could lead to denials or maladaptive behaviours with attendant vulnerability consequences (Grothmann \& Patt, 2005; Jones \& Boyd, 2011). To reduce vulnerability and promote resilience, the communities will have to understand the cause of climate change and take action to adapt. Although Nigeria has developed macro-level strategies including ratifying the Paris Agreement and submitting in 2017 its first Nationally Determined Contribution (NDC), highlighting through the National Adaptation Strategy and Plan of Action for Climate Change Nigeria (NASPA-CCN) its future adaptation priorities (World Bank, 2019), more needs to be done on the implementation at the local levels. 
As some research participants did nothing to adapt to climate change, this could be linked to others who pray and make sacrifices as climate change response strategies. Therefore, we suggest that any participatory adaptation planning will have to be sensitive to belief systems or indeed use analogous religious stories where changes are advocated according to certain doctrines. In addition, we recommend more awareness creation on causes and effects of climate change which will be more beneficial to employing more tangible adaptation strategies. Policy makers should also focus more on investments towards integrating cultural beliefs to climate change adaptation policies in order to reduce farmers' vulnerability and more attention should be focused towards promoting practical actions that will lead to long-term climate change adaptation compared to relying more on prayers and sacrifices.

Funding: This research did not receive any specific grant from funding agencies in the public, commercial, or not-for-profit sectors. 


\section{References}

Abaje, I. B. (2014). Climate Variability and Change, Impacts and Adaptation Strategies in Dutsin-Ma Local Government Area of Katsina State, Nigeria (Vol. Vol. 6).

Abiodun, B. J., Salami, A. T., \& Tadross, M. (2011). Climate Change Scenarios for Nigeria: Understanding Biophysical Impacts, Climate Systems Analysis Group, Cape Town, for Building Nigeria's Response to Climate Change Project. Retrieved from Ibadan, Nigeria:

Adger, N. W., Arnell, N. W., \& Tompkins, E. L. (2005). Successful adaptation to climate change across scales. Global Environmental Change, 15(2), 77-86. doi:https://doi.org/10.1016/j.gloenvcha.2004.12.005

Adger, W. (2006). Vulnerability. Global Environmental Change, 16, 268-281. doi:10.1016/j.gloenvcha.2006.02.006

Adger, W. N., Barnett, J., Brown, K., Marshall, N., \& O'Brien, K. (2012). Cultural dimensions of climate change impacts and adaptation. Nature Climate Change, 3, 112. doi:10.1038/nclimate1666

Adger, W. N., Dessai, S., Goulden, M., Hulme, M., Lorenzoni, I., Nelson, D. R., . . Wreford, A. (2009). Are there social limits to adaptation to climate change? Climatic Change, 93(3), 335-354. doi:10.1007/s10584-008-9520-z

Antwi-Agyei, P., Dougill, A. J., Stringer, L. C., \& Codjoe, S. N. A. (2018). Adaptation opportunities and maladaptive outcomes in climate vulnerability hotspots of northern Ghana. Climate Risk Management, 19, 83-93. doi:https://doi.org/10.1016/j.crm.2017.11.003

Artur, L., \& Hilhorst, D. (2012). Everyday realities of climate change adaptation in Mozambique. Global Environmental Change, 22(2), 529-536. doi:https://doi.org/10.1016/i.gloenvcha.2011.11.013

Ashraf, M., \& Routray, J. K. (2013). Perception and understanding of drought and coping strategies of farming households in north-west Balochistan. International Journal of Disaster Risk Reduction, 5, 49-60. doi:https://doi.org/10.1016/i.ijdrr.2013.05.002

Bandura, A. (1997). Self-efficacy: The exercise of control. New York: Freeman.

Banham, R. (no date). Myth and religion. In (pp. Description of Nut and Geb (Egyptian sky goddess and earth god) after a papyrus illustration of the Book of the Dead). Reading: University of Reading

Batterbury, S. J., \& Mortimore, M. (2013). Adapting to drought in the West African Sahel. In S. Boulter, J. Palutikof, D. Karoly, \& D. Guitart (Eds.), Natural Disasters and Adaptation to Climate Change (pp. 149-157). Cambridge: Cambridge University Press.

Blum, A. (2017). Osmotic adjustment is a prime drought stress adaptive engine in support of plant production. Plant, Cell \& Environment, 40(1), 4-10. doi:10.1111/pce.12800

Boko, M., Niang, I., Nyong, A., Vogel, C., Githeko, A., Medany, M., .. Yanda, P. (2007). Africa. In M. L. Parry, O. F. Canziani, J. P. Palutikof, P. J. Van Der Linden, \& C. E. Hanson (Eds.), Climate change (2007): Impacts, adaptation and vulnerability. Contribution of working group II to the fourth assessment report of the IPCC (pp. 433-467). Cambridge: Cambridge University Press.

Chitando, E. (2017). Praying for Courage: African Religious Leaders and Climate Change. The Ecumenical Review, 69(3), 425-435. doi:10.1111/erev.12304

Cutter, S. L. (2006). Hazards, Vulnerability and Environmental Justice. Abingdon, Oxon: Taylor and Francis Earthscan.

Dawson, C. (2009). Introduction to Research Methods: A practical guide for anyone undertaking a research project (Fourth ed.). Begbroke, Oxford: How To Books Ltd.

Dei, G. J. S. (1994). INDIGENOUS AFRICAN KNOWLEDGE SYSTEMS: LOCAL TRADITIONS OF SUSTAINABLE FORESTRY. Singapore Journal of Tropical Geography, 14(1), 28-41. doi:10.1111/j.1467-9493.1994.tb00222.x

Dixon, L. J., Stringer, C. L., \& Challinor, J. A. (2014). Farming System Evolution and Adaptive Capacity: Insights for Adaptation Support. Resources, 3(1). doi:10.3390/resources3010182

Dumenu, W. K., \& Obeng, E. A. (2016). Climate change and rural communities in Ghana: Social vulnerability, impacts, adaptations and policy implications. Environmental Science \& Policy, 55, 208-217. doi:https://doi.org/10.1016/i.envsci.2015.10.010 
FAO. (2018). Small Family Farms Country Factsheet - Nigeria. Retrieved from Rome: http://www.fao.org/3/19930EN/i9930en.pdf

Farauta, K. B., Egbule, C. L., Idrisa, Y. L., \& Agu, V. C. (2011). Farmers' Perceptions of Climate Change and Adaptation Strategies in Northern Nigeria: An Empirical Assessment. Retrieved from Nairobi, Kenya:

Forster, P. G. (1998). Religion, Magic, Witchcraft, and AIDS in Malawi. Anthropos, 93(4/6), 537-545.

Fountain, P. M., Kindon, S. L., \& Murray, W. E. (2004). Christianity, Calamity, and Culture: The Involvement of Christian Churches in the 1998 Aitape Tsunami Disaster Relief. the Contemporary Pacific, 16(2), 321-355.

Gallopín, G. C. (2006). Linkages between vulnerability, resilience, and adaptive capacity. Global Environmental Change, 16(3), 293-303. doi:http://dx.doi.org/10.1016/i.gloenvcha.2006.02.004

Godfray, H. C. J., Beddington, J. R., Crute, I. R., Haddad, L., Lawrence, D., Muir, J. F., . . Toulmin, C. (2010). Food Security: The Challenge of Feeding 9 Billion People. Science, 327(5967), 812. doi:10.1126/science. 1185383

Grothmann, T., \& Patt, A. (2005). Adaptive capacity and human cognition: The process of individual adaptation to climate change. Global Environmental Change, 15(3), 199-213. doi:http://dx.doi.org/10.1016/j.gloenvcha.2005.01.002

Hanjra, M. A., \& Qureshi, M. E. (2010). Global water crisis and future food security in an era of climate change. Food Policy, 35(5), 365-377. doi:http://dx.doi.org/10.1016/i.foodpol.2010.05.006

Hiwasaki, L., Luna, E., Syamsidik, \& Marçal, J. A. (2015). Local and indigenous knowledge on climaterelated hazards of coastal and small island communities in Southeast Asia. Climatic Change, 128(1), 35-56. doi:10.1007/s10584-014-1288-8

Hulme, M. (2009). Why we disagree about climate change: Understanding controversy, inaction and opportunity. New York: Cambridge University Press.

IPCC. (2001). Climate Change: The Scientific Basis. Retrieved from Geneva, Switzerland: https://archive.ipcc.ch/ipccreports/tar/wg1/index.php?idp=0

IPCC. (2012). Summary for Policymakers. In C. B. Field, V. Barros, T. F. Stocker, D. Qin, D. J. Dokken, K. L. Ebi, M. D. Mastrandrea, K. J. Mach, G. K. Plattner, S. K. Allen, M. Tignor, \& P. M. Midgley (Eds.), Managing the Risks of Extreme Events and Disasters to Afdvance Climate Change Adaptation (pp. 1-19). Cambridge, UK: University Press.

Irohibe, I., \& Agwu, E. (2014). Assessment of Food Security Situation among Farming Households in Rural Areas of Kano State, Nigeria. 15, 94-107. doi:10.5513/JCEA01/15.1.1418

Jellason, P. N., Baines, N. R., Conway, S. J., \& Ogbaga, C. C. (2019). Climate Change Perceptions and Attitudes to Smallholder Adaptation in Northwestern Nigerian Drylands. Social Sciences, 8(2). doi:10.3390/socsci8020031

Jones, L., \& Boyd, E. (2011). Exploring social barriers to adaptation: Insights from Western Nepal. Global Environmental Change, 1262-1274. doi:https://doi.org/10.1016/i.gloenvcha.2011.06.002

Kirkpatrick, L. A. (2005). Attachment, Evolution, and the Psychology of Religion. New York: Guilford Press.

Krueger, R. A. (Producer). (2002, 06/08/2019). Designing and Conducting Focus Group Interviews. Retrieved from https://www.eiu.edu/ihec/Krueger-FocusGrouplnterviews.pdf

Kurukulasuriya, P., Mendelsohn, R., Hassan, R., Benhin, J., Deressa, T., Diop, M., . . Dinar, A. (2006). Will African Agriculture Survive Climate Change? World Bank Economic Review, 20(3), 367388. doi:10.1093/wber/lhl004

Kuruppu, N. (2009). Adapting water resources to climate change in Kiribati: the importance of cultural values and meanings. Environmental Science \& Policy, 12(7), 799-809. doi:https://doi.org/10.1016/j.envsci.2009.07.005

Mabuku, M. P., Senzanje, A., Mudhara, M., Jewitt, G. P. W., \& Mulwafu, W. O. (2019). Strategies for coping and adapting to flooding and their determinants: A comparative study of cases from 
Namibia and Zambia. Physics and Chemistry of the Earth, Parts $A / B / C, 111,20-34$. doi:https://doi.org/10.1016/i.pce.2018.12.009

Mbiti, J. S. (2015). Introduction to African Religion (2nd ed.). Illinois: Waveland Press.

McNeeley, S. M., \& Lazrus, H. (2014). The Cultural Theory of Risk for Climate Change Adaptation. Weather, Climate, and Society, 6(4), 506-519. doi:10.1175/WCAS-D-13-00027.1

Mehar, M., Mittal, S., \& Prasad, N. (2016). Farmers coping strategies for climate shock: Is it differentiated by gender? Journal of Rural Studies, 44, 123-131. doi:http://dx.doi.org/10.1016/j.jrurstud.2016.01.001

Morgan, D. L., \& Scannell, A. U. (1998). Planning Focus Groups (Focus Group Kit 2 ed.). London: SAGE Thousand Oaks.

Murphy, C., Tembo, M., Phiri, A., Yerokun, O., \& Grummell, B. (2016). Adapting to climate change in shifting landscapes of belief. Climatic Change, 134(1), 101-114. doi:10.1007/s10584-0151498-8

National Bureau of Statistics. (2018). Labour Force Statistics: Employment by Sector Report - Q1-Q3 2017. Retrieved from Abuja Nigeria: https://www.proshareng.com/admin/upload/reports/10910ProshareConfidentialDecember2017-proshare.pdf

Nelson, D. R., \& Finan, T. J. (2009). Praying for Drought: Persistent Vulnerability and the Politics of Patronage in Ceará, Northeast Brazil. American Anthropologist, 111(3), 302-316.

Olupona, J. (2006). Religion and ecology in African culture and Society. In R. S. Gottlieb (Ed.), The Oxford handbook of religion and ecology. New York: Oxford University Press.

Orlove, B., Roncoli, C., Kabugo, M., \& Majugu, A. (2010). Indigenous climate knowledge in southern Uganda: the multiple components of a dynamic regional system. Climatic Change, 100(2), 243265. doi:10.1007/s10584-009-9586-2

Osbahr, H., Twyman, C., Neil Adger, W., \& Thomas, D. S. G. (2008). Effective livelihood adaptation to climate change disturbance: Scale dimensions of practice in Mozambique. Geoforum, 39(6), 1951-1964. doi:10.1016/j.geoforum.2008.07.010

Pew Forum. (2010). Tolerance and Tension: Islam and Christianity in Sub-Saharan Africa. Retrieved 04/07/2019, from Pew Research Centre https://www.pewresearch.org/wpcontent/uploads/sites/7/2010/04/sub-saharan-africa-full-report.pdf

Reed, M. S., \& Stringer, L. C. (2016). Land Degradation, Desertification and Climate Change: Anticipating, assessing and adapting to future change. London: Earthscan from Routledge.

Royal Society. (2009). Reaping the benefits: Science and the sustainable intensification of global agriculture. Retrieved from London:

Salite, D. (2019). Explaining the uncertainty: understanding small-scale farmers' cultural beliefs and reasoning of drought causes in Gaza Province, Southern Mozambique. Agriculture and Human Values. doi:10.1007/s10460-019-09928-z

Salite, D., \& Poskitt, S. (2019). Managing the impacts of drought: The role of cultural beliefs in smallscale farmers' responses to drought in Gaza Province, southern Mozambique. International Journal of Disaster Risk Reduction, 41, 101298. doi:https://doi.org/10.1016/j.ijdrr.2019.101298

Schipper, E. L. F. (2010). Religion as an integral part of determining and reducing Climate Change and Disaster Risk: An agenda for research. In M. Voss (Ed.), Der Klimawandel: Sozialwissenschaftliche Perspektiven (pp. 377-393). Wiesbaden: VS Verlag für Sozialwissenschaften.

Schuman, S., Dokken, J.-V., van Niekerk, D., \& Loubser, R. A. (2018). Religious beliefs and climate change adaptation: A study of three rural South African communities. Jamba (Potchefstroom, South Africa), 10(1), 509-509. doi:10.4102/jamba.v10i1.509

Slegers, M. F. W. (2008). "If only it would rain": Farmers' perceptions of rainfall and drought in semiarid central Tanzania. Journal of Arid Environments, 72(11), 2106-2123. doi:https://doi.org/10.1016/i.jaridenv.2008.06.011 
Spear, D., Haimbili, E., Angula, M., Baudoin, M.-A., Hegga, S., Zaroug, M., \& Okeyo, A. (2015). Vulnerability and Adaptation to Climate Change in the Semi-Arid Regions of Southern Africa. Retrieved from Ottawa, Canada:

Spear, D., Selato, J. C., Mosime, B., \& Nyamwanza, A. M. (2019). Harnessing diverse knowledge and belief systems to adapt to climate change in semi-arid rural Africa. Climate Services, 14, 3136. doi:https://doi.org/10.1016/i.cliser.2019.05.001

Stewart, D. W., \& Shamdasani, P. N. (2014). Focus Groups: Theory and Practice (3rd ed.). London: SAGE.

Tambo, J. A., \& Abdoulaye, T. (2013). Smallholder farmers' perceptions of and adaptations to climate change in the Nigerian savanna. Regional Environmental Change, 13(2), 375-388. doi:10.1007/s10113-012-0351-0

UNFCCC. (2015). Nigeria's Intended Nationally Determined Contribution. Retrieved from Germany: https://www4.unfccc.int/sites/ndcstaging/PublishedDocuments/Nigeria\%20First/Approved \%20Nigeria\%27s\%20INDC 271115.pdf

Westley, F., Carpenter, S. R., Brock, W. A., Holling, C. S., \& Gunderson, L. H. (2002). Why Systems of People and Nature Are Not Just Social and Ecological Systems. In L. H. Gunderson \& C. S. Holling (Eds.), Panarchy: Understanding Transformations in Human and Natural Systems (pp. 103-119). London: Island Press.

World Bank. (2019). Climate Change Knowledge Portal for Development Practitioners and Policy Makers- Nigeria Country Context. from World Bank Group https://climateknowledgeportal.worldbank.org/country/nigeria

Yeletaysi, S., Ozceylan, D., Fiedrich, F., Harrald, J. R., \& Jefferson, t. (2009). A Framework to integrate Social Vulnerability in to catastrophic Natural Disaster preparedness. Paper presented at the TIEMS, Istanbul, Turkey. 